there is no guarantee that the people would benefit. If the Nazis are unwilling to share the food they control with these people or even allow them to keep the food they have, it is very doubtful whether they would allow them to benefit from any food allowed in. Measures could, of course, be taken to ensure that the people received the actual food sent in, but there is nothing to prevent the Nazis, who have complete control, from withdrawing an equivalent amount of food either for the troops of occupation or for transfer to Germany. It has been suggested that dried milk and cod liver oil might be allowed in to prevent malnutrition, but the Nazis could take away an equivalent amount of dairy products.

The only way to bring relief to Europe is to defeat the Nazis and drive them out of the conquered countries. Anything which will contribute to the destruction of the Nazi war machine will contribute to the relief of the conquered people. Any food, or other material which can be used for war purposes, allowed into the part of Europe controlled by the Nazis, strengthens the Nazi war machine and, to that extent, delays the deliverance of the people of Europe. But preparations should now be made so that food and other forms of assistance may be rushed to these countries as soon as they are liberated. Attention should be given now to what foods will be most effective in rectifying the evil effects of shortage during the enemy occupation, and the organization for the transport and distribution of the food got ready.

The action which ought to be taken now and after the War should be based on facts and not on opinions formed from rumours and enemy propaganda. Until war broke out, there was an international committee of nutritional experts, including prominent American and British men of science nominated by their respective Governments. For three years before the War, this com- mittee, in collaboration with a committee of economic and agricultural experts, was engaged in studying the food position in Europe. It would be better able to assess the true position and make recommendations than any other body which could be set up. Further, it had experience of similar work in advising on food relief measures for Spain. The United States and the British Commonwealth of Nations might well appoint the American and British members of this committee, with an American chairman, to investigate the position and report on the present food position in Europe in so far as information is available, the means which ought to be taken to relieve distress arising from food shortage in Europe, and also on the economic and political measures which should be taken to base post-War world food policy on nutritional needs. In its pre-War studies, this committee found that the basing of food policy in the nutritional néeds of the people would, in addition to bringing about a great reduction in disease and a rise in the standard of living, bring prosperity to agriculture and increase international trade. The committee suggested could make sound recommendations based on ascertained fact to deal with the present position, and could also make an important contribution to the building up of the new and better world order we are looking for after the War.

Every means should then be taken to let the people in Nazi-occupied Europe know that the free countries are making elaborate preparations to bring food and other forms of assistance as soon as the Nazis are defeated. The knowledge that these preparations were being made on the recommendation of a committee of scientific men, all of whose names are well-known in every country in Europe, would help them to endure the evils of their temporary bondage and encourage them, at the appropriate time, to assist in their own deliverance.

\title{
TRADITION IN A NEW WORLD ORDER
}

$\mathrm{W}^{\mathrm{E}}$ E live in the birth-pangs of a new world. Of what order that world will be now hangs on the arbitrament of war. Should the final decision be, as we hope and confidently expect, in favour of Great Britain and her Allies, to them will fall the task of moulding the new world in that shape which the ideals and principles for which we have taken up the challenge of dictators and totalitarian States may best be given practical effect. The burden will be heavy; and not the least onerous part of the task will be how best to ensure that in the endeavour to attain a state of permanent peace in the future by bringing about co-operation between peoples and nations in all matters which pertain to the common interests of mankind, loyalty to these principles and ideals 
may be maintained without impairing either sense of freedom in action or individuality. At the close of the War of 1914-18 it is true that these elements of freedom and individuality were stressed over-strongly. The rights of minorities and the claims of the smaller national groups to selfdetermination were allowed to obscure the larger issue. This was largely a consequence, perhaps inevitable, of conditions which had preceded that great struggle. But when the time came for the League of Nations to take the strain, instead of a united team it proved to be rather an assemblage of disruptive forces in which sovereignty and national self-interest acted as the motive power and obscured the urgency of adherence to a common aim. The tradition of national and racial groupings, in the long run, rendered impotent attempts to secure full corporate action on the occasion of any major political crisis. A world which was to be "made safe for democracy", in the event, through the assertion of national claims in both the political and the economic spheres, became the opportunity of the dictator and of those whose specious arguments even in nontotalitarian States placed a delusive efficiency in public affairs above free discussion. In the result, democracy has been brought within measurable distance of the danger of extinction.

Many writers over a long period of years have prophesied the coming of Armageddon, when man would destroy himself and the civilization he has constructed by misuse of the powers of his own intellect and his control over the forces of Nature. Among recent writers Mr. H. G. Wells, in some of his early works, has drawn horrific pictures of a derelict world after the last great struggle has been fought to a finish. On the other hand, others, among whom Sir Arthur Keith has been conspicuous, have seen in war a moulding force by virtue of which racial, or rather national, types and characteristics are evolved. Without accepting the argument as valid in its entirety, it may at least be admitted that as a result in part of conditions arising out of the War of 1914-18 three new forms of political organization emerged-the League of Nations, the Russian Union of Soviets, and the British Commonwealth of Nations. Each of these was, in its respective method of approach to the problem of uniting a number of peoples in a single grouping, a step forward along the line of development of ever-increasing social and political units which is apparent in the evolution of human societies. Of the third of these, however, the British Commonwealth of Nations, it is perhaps not over-hazardous to say that it possessed the best chance of survival as being the least counter to tradition. It is in harmony with the trend of British institutions which have fostered local autonomy, not only in Great Britain itself in its municipal, district and county administrative bodies, but also in the legislative councils which hitherto had been responsible under the Imperial Government for the affairs of the Dependencies. At the same time the British Commonwealth stands alone in the history of political institutions in that it is a body composed of free and independent nations, in which any act of aggression of one member against another is well-nigh inconceivable.

The League of Nations was the latest of attempts since the Pax Romana and the Roman Empire to unite the peoples of Europe, or the greater number of them, in a single system. It differed from its forerunners in that it did not aim at complete political unity, but only at joint and corporate action in certain spheres of political, social and intellectual interest; it went outside the geographical boundaries of Europe and appealed for the co-operation of peoples of European civilization; and, most significant of all its differences from previous systems, it was based upon the voluntary principle and a degree of abrogation of sovereignty, and not upon force. It is, therefore, perhaps no matter for surprise that its most conspicuous success was precisely in those fields of activity in which before the first world war, interest, activities and joint action had been international and the barriers of national interests had been least operative- - the field of the arts, sciences and social reform. In this respect it came near to reconstituting the international position of learning and the arts in Europe before the Reformation.

The fate of the League of Nations was a clear indication that the times were not yet ripe for so great a break away from the nationalist tradition. It has required the shock of a second world war and the imminent peril of free institutions throughout the world to bring once more into the field of practicable discussion the possibility of finding a basis of corporate action between nations which will ensure conditions of enduring peace. We may learn this lesson not only from America, where the President of the United States is urging upon peoples of very different civilizations in North, Central and South America, the necessity of a measure of common action in the interests of their common devotion to the ideal of political 


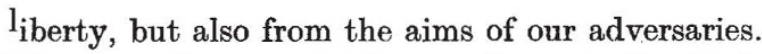
They too, Germany in Europe, Japan in the East, are formulating a political system which transcends national distinctions, but under the dominance of a ruling caste $-a$ reversion, it is to be noted, to the system of barbarism which in European history followed on the period of migrations rather than a step forward along the line of what has been noted as evolutionary social development. German dominance, however, in the occupied territories and in the countries subordinate to the Axis contrasts, to its disadvantage, with even the darker period of the Middle Ages in the complete repression of things of the spirit and the eradication of all freedom of thought by the suppression of universities, schools and centres of learning which are not prepared to follow the paths marked out by political expediency.

Over against this spreading cloud which seeks to blot out every path leading to the development of the spirit of man, there stands Great Britain, her Allies and every free people which holds fast to the ideas of democracy, even though they may not yet go all the way with the United States in giving Great Britain every aid short of war. The aim of those who fight for the cause of democracy is not merely to ensure a lasting peace, but also that it shall be a peace in conditions which are a guarantee of the continuance of free institutions, and for the individual the fullest opportunity for the development of his character and capacities. This cannot be stated too emphatically or too frequently. In this connexion attention may be directed to a volume of speeches by Lord Halifax* in which implications of the democratic ideas as a political principle are set forth with wholly admirable lucidity and force. These speeches dealing with foreign affairs and the principles of British foreign policy were, many of them, though not all, delivered in the course of debate in the House of Lords, and the editor has provided a summary of events leading up to each speech. Hence this volume may serve as a useful reminder of the course of events in the most fateful years of the history of Great Britain. Not only do they carry great weight in their more general passages dealing with political practice and theory, but also they have special authority in the later years when Lord Halifax speaks as the Secretary of State for Foreign Affairs and the spokesman of the Government in the House of Lords.

* Speeches on Foreign Policy. By Viscount Halifax. Edited by H. H. E. Craster. Pp. $\mathrm{x}+368$. (London, New York and Toronto: Oxford University Press, 1940.) 108. 6d. net.
It is especially illuminating to recall the course of events and to note here how from faith in the League of Nations and collective security with a conciliatory attitude towards Germany, the Government passed through a phase of increasing distrust of the Nazi regime and misgiving as to the efficacy of the League, a period of regional pacts and so-called realism in international relationships and finally to complete disillusionment. Throughout, however, Lord Halifax stands fast by the ideal of democracy, from the time when in 1934, in addressing the educational section of Messrs. Rowntree's factory at York, he defined the object of government as "the fuller and freer development of human life" down to the latest speech here included, "The Challenge to Liberty," delivered at Oxford in February 1940, when he contrasted the spirit of German youth and British youth and defined British policy in the War as resting upon twin foundations of purpose-"determination to resist force" and "our recognition of the world's desire to get on with the constructive work of building peace" - the latter, as he had shown, a task which must be pursued in the Christian spirit of tolerance and justice.

While it is generally agreed that in a post-war settlement which aims at conditions of enduring peace it will be essential to bring about some form of co-operative or federal organization at the very least in Europe, it is obvious that to translate the democratic ideal into a working system presents many grave difficulties. Many practical problems have to be solved, some of which have already been discussed in the columns of NATURE. Of these, in a democracy, education on rising standards possibly comes first, but hygiene, unemployment and inter-State relations in exchange of commodities and in finance run education close. If we may learn from our adversaries, the ostensible uniformity of the system of finance and commercial relations proposed in the Nazi 'New Order' merits examination. So far as these problems approach solution so far will the task of the central organization approach fulfilment, but in both spheres, that of the practical problem and that of the affairs of the whole organization and of its relations with those outside its body, successful working will come not by the elimination of national and cultural differences, as many fear, but by their recognition and by the preservation of those forms of cultural tradition which by their very differences lead, as the history of civilization shows, to cultural advance. 